\title{
Dynamic Alterations in Growth Hormone Receptor mRNA Levels in Rat Brain During Stress Tolerance
}

\author{
TAKAHIKo FUJIKAWA, Hideo YOSHIZATO, HideaKi SOYA*, and Kunio NAKASHIMA \\ Department of Biochemistry, Faculty of Medicine, and ${ }^{*}$ Department of Health and Physical Education, \\ Faculty of Education, Mie University, Mie 514, Japan
}

IN THE RAT, GH receptor (GHR) [1] and GHbinding protein (GHBP) [2] are known to be encoded by alternatively spliced messenger RNA (mRNA) species expressed in various regions of the brain [3]. In addition to GHR mRNA, Somatostatin (SS) and GH-releasing factor (GRF) neurons are also detected in the arcuate (ARC), periventricular $(\mathrm{PeV})$ and paraventricular nuclei of the rat [4]. Several laboratories have reported that various kinds of stress decrease the circulating level of GH in the rat [5-7]. This repressive effect of stress on $\mathrm{GH}$ secretion is proposed to occur via stress-induced hypothalamic corticotropin-releasing factor (CRF) stimulating the inhibitory somatostatin release into portal blood [7]. A recent study by Martin et al. [8] has shown that the acute stress response of GH may not be correlated with the activity of peripheral sympathetic nerve terminals, which is exerted on hypophysiotropic hormone release rather than its synthesis, in the rat. It is not clear yet, however, whether or not the stress can alter the gene expression of GHR/GHBP in rat brain.

Here we report that a severe stress, restraint stress in water (RSW), increases the levels of GHR/ GHBP mRNAs in the brain of the rat.

\section{Materials and Methods}

At 10 weeks of age, male Sprague-Dawley rats were put into individual restraining wire net cag-

Correspondence to: Dr. Kunio NAKASHIMA, Department of Biochemistry, Faculty of Medicine, Mie University, 2174 Edobashi, Tsu, Mie 514, Japan

Key words: Restraint stress, GH receptor, $\mathrm{GH}$ binding protein, mRNA expression, Reverse transcriptionpolymerase chain reaction (RT-PCR), Brain es, and immersed in water $\left(23 \pm 0.5^{\circ} \mathrm{C}\right)$ to the chest. At $0.5,1,2,4$ or $7 \mathrm{~h}$ of RSW, or at 3 or $6 \mathrm{~h}$ of resting after $7 \mathrm{~h}$ of RSW, rats were taken out from restraining cages and decapitated as described previously [9]. Total RNA was isolated from rat brain (cerebrum), which was isolated from the cerebellum and pituitary gland, and RNA was diluted serially from 40 to $2.5 \mu \mathrm{g}$. Each sample was subjected to reverse transcription-polymerase chain reaction (RT-PCR) as described by Sakaguchi et al. [10]. Autoradiograms of the Southern blots were analyzed by a Machintosh-based image analyzing system with the NIH image 1.44 software. The correlations between log RNA input and densitometric measurements of autoradiograms of amplified cDNA for GHR/GHBP mRNAs were linear (Fig. 1). Ten $\mu$ g total RNA from the brain (cerebrum) was used in the subsequent experiment for RT-PCR. The mean and SEM of the data were determined and presented. The significance of differences between the values was determined by Dunnett's post-hoc procedure test after performing the Bartlett test, and $P<0.05$ was considered significant.

\section{Results}

With the RT-PCR method, the mRNA expression levels for GHR and GHBP in rat brain were determined during the course of RSW. The GHR mRNA level was started to increase at $2 \mathrm{~h}$ of RSW (Fig. 2). The increase in the GHR mRNA level was maintained during RSW and reached about three times the control level before RSW. The mRNA expression level was quickly decreased when the animals were released from the stress. It returned to the initial level in $3 \mathrm{~h}$ of rest after $7 \mathrm{~h}$ of RSW. 
A

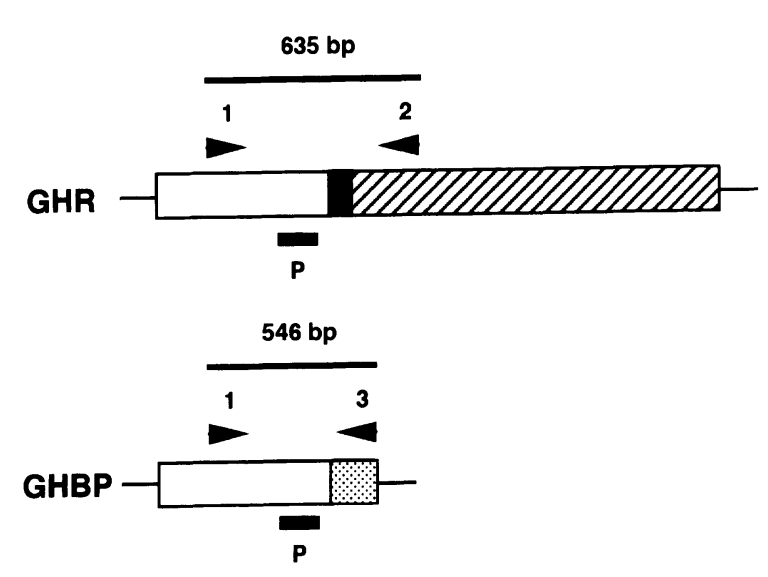

B

GHR

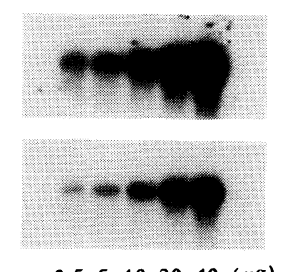

C

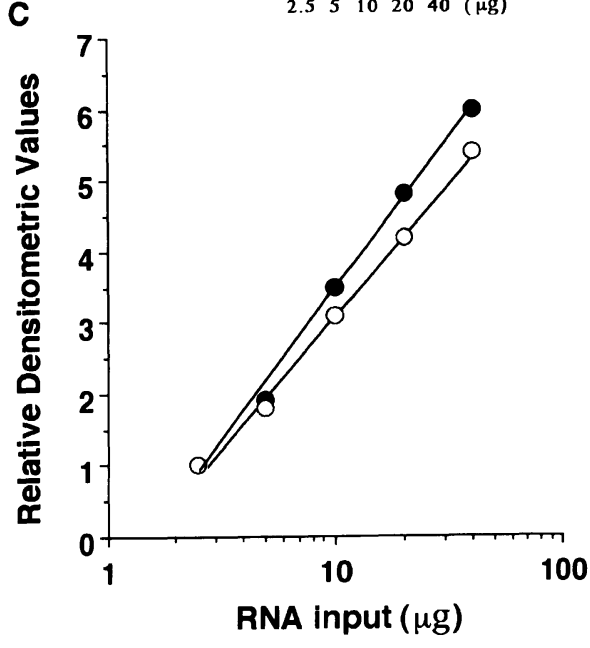

Fig. 1. A: Schematic representation and detection of cDNAs for GHR/GHBP by RT-PCR and densitometry. The open boxes indicate the extracellular regions common to GHR/GHBP, and the solid, shaded and dotted boxs indicate the transmembrane, cytoplasmic region unique to GHR and hydrophilic tail unique to GHBP, respectively. Arrowheads and $P$ indicate the positions for the primers in RT-PCR and the probe for Southern blot, respectively. B: Autoradiograms of Southern blotting of the amplified cDNA fragments C: Plots of the densitometrically determined signals in the autoradiograms for both GHR (closed circle) and GHBP (open circle).

The brain GHBP mRNA expression was similarly altered during RSW, but the expression levels were somewhat lower than that for GHR mRNA (Fig. 2).

The animals released from $7 \mathrm{~h}$ of RSW quickly recovered physically and emotionally.

\section{Discussion}

The present study has shown that the severe stress, RSW, induces obvious enhancement of GHR/GHBP gene expressions in the rat brain. In a previous study [9], we observed that the mRNA expression of long form PRL receptor was remarkably enhanced in rat brain during RSW. The result of the present study suggests that $\mathrm{GH}$ as well as PRL may act directly on the brain during tolerance of stress. Recently, several studies have provided convincing evidence that $\mathrm{GH}$ can pass the bloodbrain barrier (BBB) via a receptor-mediated mechanism in the choroid plexus [11, 12] and may affect central nervous system eliciting the well-being feeling [13]. In the rat tissues, the correlations between GHR gene expression and GHR/GHBP protein production are not clear yet. A recent study on dwarf rat by Gabrielsson et al. [14] has shown that continuous hGH infusions induce GHR1 transcripts in the liver, resulting in increases in GHR/ GHBP proteins. They also reported that dexamethasone, which was given in the drinking water for 12 days, reduced both protein and mRNA levels of hepatic GHR. Our present results, however, showed that the expression of brain GHR mRNA was increased in $2 \mathrm{~h}$ of dexamethasone treatment (20 $\mu \mathrm{g}$, i.v.), and the elevated mRNA level was then decreased after $4 \mathrm{~h}$ of the treatment, probably by down-regulation (data not shown). Further studies are need to elucidate the molecular mechanism inducing mRNA expressions in the brain for GHR and GHBP. 


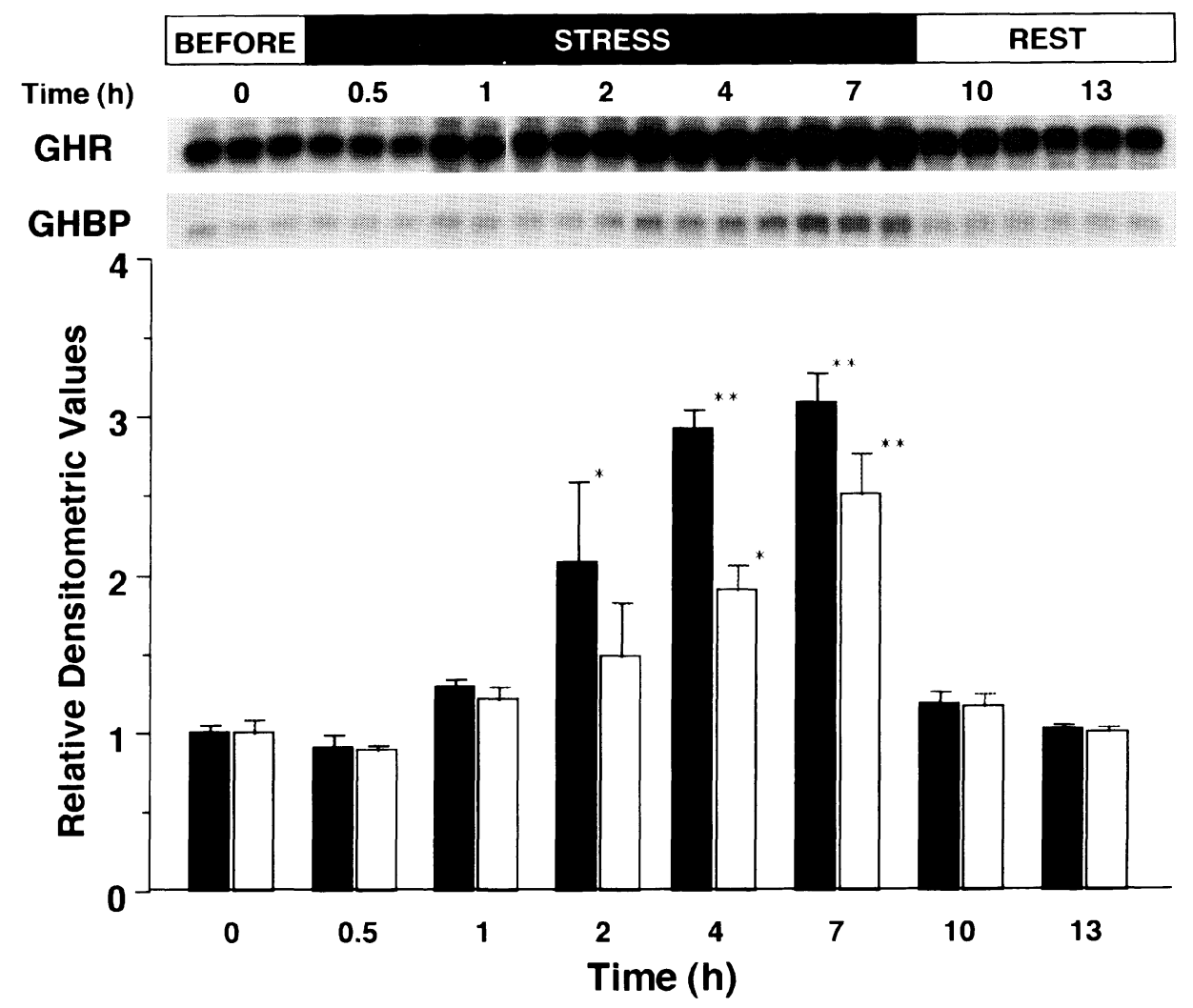

Fig. 2. Autoradiograms and densitometoric determinations of GHR and GHBP mRNAs during RSW. The mRNAs for GHR (closed bars) and GHBP (open bars) were determined before RSW $(0 \mathrm{~h})$, during the course of RSW $(0.5-7 \mathrm{~h})$, and after 3 and 6 $\mathrm{h}$ of rest following $7 \mathrm{~h}$ of RSW $(10$ and $13 \mathrm{~h}$ ). The data were the means of triplicate experiments. ${ }^{*}, P<0.05 ;{ }^{*}, P<0.005$ (compared with the values at time zero, respectively).

\section{References}

1. Mathews LS, Enberg B, Norstedt G (1989) Regulation of rat growth hormone receptor gene expression. J Biol Chem 264: 9905-9910.

2. Baumbach WR, Horner DL, Logan JS (1989) The growth hormone-binding protein in rat serum is an alternatively spliced form of the rat growth hormone receptor. Gene Dev 3: 1199-1205.

3. Lobie PE, García-Aragón J, Lincoln DT, Barnard R, Wilcox JN, Waters MJ (1993) Localization and ontogeny of growth hormone receptor gene expression in the central nervous system. Dev Brain Res 74: 225-233.

4. Burton KA, Kabigting EM, Clifton DK, Steiner RA (1992) Growth hormone receptor messenger ribonucleic acid distribution in the adult male rat brain and its colocalization in hypothalamic somatostatin neurons. Endocrinology 131: 958-963.

5. Eck JB, Kuhn CM (1992) Effect of ether stress on growth hormone during development in the neonatal rat. Neuroendocrinology 56: 605-610.

6. Kjar A, Knigge U, Bach FW, Warberg J (1995) Stressinduced secretion of pro-opiomelanocortin-derived peptides in rats: Relative importance of the anterior and intermediate pituitary lobes. Neuroendocrinology 61: 167-172.

7. Rivier C, Vale W (1985) Involvement of corticotropin-releasing factor and somatostatin on stress-induced inhibition of GH secretion in the rat. Endocrinology 117: 2478-2482.

8. Martín AI, López-Calderón A, Tresguerres JAF, González-Quijano, Cardinali DP (1995) Restraintinduced changes in serum luteinizing hormone, prolactin, growth hormone and corticosterone levels in rats: Effect of superior cervical ganglionectomy. Neuroendocrinology 61: 173-179.

9. Fujikawa T, Soya H, Yoshizato H, Sakaguchi K, 
Doh-ura K, Tanaka M, Nakashima K (1995) Restraint stress enhances the gene expression of prolactin receptor long form at the choroid plexus. Endocrinology 136: 5608-5613.

10. Sakaguchi K, Ohkubo T, Sugiyama T, Tanaka M, Ushiro H, Nakashima K (1994) Differential regulation of prolactin receptor mRNA expression in rat liver and kidney by testosterone and oestradiol. J Endocrinol 143: 383-392.

11. Stern WC, Miller M, Resnick O, Morgane PJ (1975) Distribution of ${ }^{125} \mathrm{I}$-labelled rat growth hormone in regional brain areas and peripheral tissue of the rat. Am J Anat 144: 503-508.

12. Lai Z, Emtner M, Roos P, Nyberg F (1991) Charac- terization of putative growth hormone receptors in human choroid plexus. Brain Res 546: 222-226.

13. Burman P, Broman JE, Hetta J, Wiklund I, Erfurth EM, Hagg E, Karlsson FA (1995) Quality of life in adults with growth hormone $(\mathrm{GH})$ deficiency: Response to treatment with recombinant human $\mathrm{GH}$ in a placebo-controlled 21-month trial. J Clin Endocrinol Metab 80: 3585-3590.

14. Gabrielsson BG, Carmignac DF, Flavell DM, Robinson ICAF (1995) Steroid regulation of growth hormone $(\mathrm{GH})$ receptor and $\mathrm{GH}$-binding protein messenger ribonucleic acid in the rat. Endocrinology 136: 209-217. 